\title{
2
}

\section{Justice within the National Imaginary: Civil society and societal transition in Timor-Leste}

\author{
Damian Grenfell
}

Since the end of the Indonesian occupation of Timor-Leste in 1999 there has been much energy expended by activists, international aid agencies, non-governmental organisations (NGOs) and United Nations (UN) agencies towards ensuring a sustainable civil society. Such an effort can be understood for a range of reasons: the necessity of responding to immense suffering following 24 years of occupation; the need for broad societal participation in the creation of a new state and nation; and as a reflection of the commonly held view that a liberal democracy requires an active civil society. Given the extraordinary material destruction, mass displacement and wide-ranging human rights abuses that occurred as a result of the Indonesian occupation, civil society actors working in the field of transitional justice have concentrated efforts in Timor-Leste since in two key ways: first, through attempts to support victims; and second, to ensure that those responsible for crimes are held to account.

1 I would like to thank my colleagues in the Centre for Global Research at RMIT University in Melbourne, Australia, and the Instituto de Ciências Sociais (ICS) at the Universidade de Lisboa where I was based while drafting this chapter. 
While civil society very often plays an important role in transitional justice efforts, the experience of Timor-Leste demonstrates that any assumption of a necessarily positive impact should at least be met with caution. As the key contention for this chapter, it is argued that as long as civil society remains anchored within a 'national imaginary' it can, at certain points, relegate or even diminish forms of recognition important to victims. This is especially the case where patterns of mourning and remembrance do not sit in commensurate relation with the 'nation'. In the continuing need to identify the fate of the missing or advocate for justice for those accused of human rights violations, for example, civil society efforts have been drawn into a fraught relationship with the state. Moreover, the experiences of victims have often been embedded discursively in national terms rather than reflecting the localised sociocultural patterns of remembering the dead and missing.

To make this argument, the chapter opens with a conceptual discussion that distinguishes civil society from the state on the basis that each are founded in different forms of legitimacy and each have a different relationship to the use of violence. Even as the state and civil society remain distinct in key ways, the second section nevertheless argues that civil society actors in Timor-Leste have often imagined justice largely in national terms, reinforcing the same territorial dimensions that demarcate state sovereignty. The third section draws the first two together to demonstrate that the emphasis given to the nation by civil society actors has limited the effectiveness of transitional justice efforts to some extent. Justice framed in national terms has on the one hand been undermined by an antagonistic state, while on the other it has risked alienating survivors and families of those killed and missing. In terms of the latter, this occurs both discursively and in practice via attempts to 'draw together' a wartorn society in ways that may not always give adequate priority to victims, including in the forms of recognition given to the dead and missing.

The ideas in this chapter are based on interviews with civil society actors in Timor-Leste between 2003 and 2017, analysis of policy and programmatic documents, project-related work within civil society and donor organisations, and general observation. The arguments made here are not of absolutes but of important trajectories and do not seek to diminish the many social benefits generated by civil society actors. It is nevertheless important to identify points of possible tension between the contributions of transitional justice processes to nation-building on one the hand and the needs of those who have suffered on the other. 


\section{Civil society and transitional justice}

Transitional justice refers to a multifaceted process that simultaneously accounts for the crimes of perpetrators while creating new systems of justice in societies that have experienced widespread violence (Brahm 2007; Grenfell 2009; Lambourne 2009, 34, 36). For Andrieu (2010, 540), transitional justice represents 'nothing less than the transformation, or regeneration, of a whole society' requiring a range of interventions. Civil society actors are typically central to this process, and in TimorLeste transitional justice initiatives have included support for victims' material restoration, assisting displaced peoples, locating the missing, collecting the remains of the dead, recording the experience of survivors, commemorating and memorialising incidents from the occupation, holding reconciliation events, promoting human rights, campaigning for an international tribunal to bring Indonesian perpetrators to trial, as well as developing a formal justice system. Together such practices are often assumed by policy actors, donors and academics as pivotal to 'ending the cycles of violence' (Minow 2002; Kovras 2012) in post-conflict states, drawing the intimate experiences of violence into larger societal frameworks that achieve a 'transition' in society.

To explore the tensions between programmatic assumptions and the needs of victims, it is important that some definitional shape is given to the concept of civil society. While 'civil society' is frequently employed in justice and peacebuilding literature, its actual meaning is often left implicit. In some instances it is defined empirically, for example by a typology of organisations, while elsewhere it is described by negation, as Gray and co-authors acknowledge:

civil society (of which NGOs are an element) is that which exists between other elements of our social world and hence, civil society is defined by what it is not. Definition is, as a result, difficult and contingent on definitions/descriptions of the other elements of society from which civil society emerges. Changes in these other elements will, likewise, affect the size and character of civil society (Gray, Bebbington and Collison 2006, 322).

What is meant by the other 'elements' tends to shift according to ideology and context, though they typically include government (or state), market (or capital) and the family (or private sphere), with the 'civil' broadly encompassing other associations and collaborations that comprise social 
life. Civil society is not, however, simply the sum of the 'rest' of society, but defined in this chapter rather as marked by two key traits: first, in terms of the legitimating claim to civic virtue; and second, via a particular kind of relationship to violence.

In terms of the first trait, in accounting for associations outside of the state the 'civil' in civil society refers to actions that in some way claim to be for the wider benefit of a particular community. Such claims will differ remarkably and, as such, do not suggest a homogeneity other than the activity is legitimated by the claim that it positively contributes to social needs, wellbeing or sustainability. The emphasis on both its associational nature and public virtue has meant that civil society is often strongly associated with either the creation or the maintenance of democratic society as discussed by Foley and Edwards (1996) in a response to Michael Walzer (1992).

In the rough pastiche that has become the commonly accepted version, a 'dense network of civil associations' is said to promote the stability and effectiveness of the democratic polity through both the effects of association on citizens' 'habits of the heart' and the ability of associations to mobilize citizens on behalf of public causes. Emergent civil societies in Latin America and Eastern Europe are credited with effective resistance to authoritarian regimes, democratizing society from below while pressuring authoritarians for change. Thus, civil society, understood as the realm of private voluntary association, from neighborhood committees to interest groups to philanthropic enterprises of all sorts, has come to be seen as an essential ingredient in both democratization and the health of established democracies (Foley and Edwards 1996, 38).

While civil society actors may make this claim at all different levels of society - including at the most local community level - in the case of transitional justice in Timor-Leste public benefit or 'cause' has been largely framed in terms of the potential contribution to nation-building in the wake of conflict. Speaking more generally, Shils points to the importance of the connection between civil society and the state by arguing that 'nationality is a necessary ingredient, perhaps even precondition for civil society. It is the collective self-consciousness which sustains the civil society. Concern for one's nation reinforces the concern for the common good' (Shils 1995, 116). While perhaps overstating the case, Shils points to an important aspect that is common to civil society actors: namely that 
the nation frequently sets the methodological and operational parameters to how activities are organised and the terms on which a 'common good' are imagined. How this relates more specifically to transitional justice is discussed in the next section, though here the point is that the kind of 'civicness' displayed is very often done so in national terms.

A second defining trait is that civil society actors do not challenge the state's claim to the monopoly over the legitimate use of violence within a given territory. Such an approach clearly adapts Weber's famous definition of the state (Gerth and Mills 1946, 77), albeit by following Gray and others in forming definitions based on other 'contingent elements of society', namely the state. The key here is to delineate the purpose of the violence, as civil society actors frequently contest the state including to the point of violence - seen often for instance with civil rights groups, unions and as part of social movement protests. ${ }^{2}$ The important difference to highlight here is that between violence that is used towards specific objectives or occurs incidentally compared to that which overtly challenges the central legitimating claims of the state. Armed social movements may be thoroughly coherent in their claims to act for a common good and be recognised as having widespread authority. Nevertheless, in challenging the foundational legitimacy of the state, such groups and movements transition out of the category of civil society actors. ${ }^{3}$

In the case of Timor-Leste, FALINTIL ${ }^{4}$ - the armed force for East Timorese independence during the Indonesian occupation - was part of a larger movement that included civil society actors. However, given its own commitment to the violent overthrow of a state, FALINTIL itself is understood here as an actor located outside of civil society. Even as

2 For example, a key policy platform of government may be challenged in strident terms and via large-scale mobilisation of people - as was the case in Timor-Leste when the Catholic Church demonstrated against government changes to school curriculums in 2005 - but when it does not challenge the core legitimacy of the state then such groups remain as part of civil society.

3 This position is distinct to that of the work of authors such as Labigne and Nassauer who name three distinct forms of violence that occur within civil society: reformist violence, demarcation violence and non-political violence. Demarcation violence is defined as politically radical and often opposed to the state, and includes organisations such Obraz, a fascist Serbian group. Such a group is able to be included in their definition as they define civil society without any reference to its civic nature, namely as 'the arena - outside of the family, the state, and the market - which is created by individual and collective actions, organizations and institutions to advance shared interests' (Labigne and Nassauer 2012,3). As such, in effect beyond the state, family and market, any form of association is deemed as civil society, even fascistic ones. See Labigne and Nassauer (2012).

4 Forças Armadas da Libertação Nacional de Timor-Leste; Armed Forces for the National Liberation of East Timor. 
civil society actors contested Indonesia's unlawful claim to legitimate rule of Timor-Leste - and therefore ultimately shared the objectives of independence with FALINTIL - at an organisational level they did not engage directly in armed insurrection and thus remained distinct from the militarised responses to occupation.

In the post-independence period, groups such as Conselho Popular pela Defesa da República Democrática de Timor-Leste (CPD-RDTL) maintained a significant space in contesting the state (Escollano Brandão 2015) until they were disbanded by the combined efforts of the police and the military (Belun 2017). This was also the case with the Conselho Revolucionário Maubere (CRM) - a group led by a dissident commonly known as 'Mauk Moruk's - which was targeted again by joint policemilitary operations with Moruk being killed (RDTL 2015). ${ }^{6}$ Again, the approach here draws a connection between civil society and the form that the challenge to the state takes; once violence is used to challenge state legitimacy then such actors move beyond that realm (and are often named in terms of criminals, terrorists, extremists and so forth by the state they are contesting).

In short then, in this chapter civil society accounts for forms of social collaboration grounded in a public virtue that do not challenge the state's claim to the monopoly over the legitimate use of violence within a given territory. Such a relationship ebbs and flows as the state itself changes, as seen in Timor-Leste across the transition from pre- to post-independence. The Suharto regime that was in power in Indonesia for almost the full duration of the occupation of Timor-Leste permitted at times a narrow and highly prescribed civil society to counter international criticism and manage internal dissent. In comparison, the kind of liberal democratic state that has been advanced in Timor-Leste post-independence has seen a civil society that is interested in the consolidation and maintenance of democratic society, often emphasising a role in providing a 'check on government' (Bell and O'Rourke 2007; Cubitt 2013, 91). This is particularly evident through the development of local NGOs whose key

5 His actual name was Paulino Gama.

6 In 2014, civil rights monitoring group Yayasan Hak (HAK) provided an update of Parliamentary Resolution No. 5/2014 outlawing the CPD-RDTL and CRM, and initiating joint operations between the police and military targeting these groups (Asosiasaun HAK 2014). 
purpose is the monitoring of the state justice sector $\left(\mathrm{JSMP}^{7}\right)$, government spending and development projects (Lao Hamutuk), security (Belun), human rights (Yayasan Hak), as well as corruption.

In a development or post-conflict context, aid organisations and donors tend to focus on the most structured and institutionalised aspects of civil society. Local NGOs provide a point of mutual legibility that facilitate shifts in resources from international agencies into national and local contexts. In practice, this can often mean that NGOs and civil society are treated as synonymous, even though, as recognised by Holloway, civil society encompasses far greater diversity in Timor-Leste:

[The] interpretation of what constitutes civil society in Timor-Leste is very limiting and very unfortunate since it puts forward only a partial selection of Timorese organisations to represent what is, in fact, a very rich and complex series of associations and organisations. The interpretation partly springs from the language of donors who have put a high priority on supporting NGOs with their funds, and who have not identified or engaged with the richer complex of CSOs that exist in East Timor (Holloway 2004, 3).

In Timor-Leste, civil society incorporates a range of social collaborations including local, national and foreign NGOs, as well as NGO networks and umbrella organisations. However, it also extends much further encompassing religious groups, including church governance, orders, parishes, prayer groups; community groups, including women's, youth, veterans and sporting groups; a myriad of community-based organisations (CBOs); not-for-profit education providers; farmer cooperatives and collectives. While recognising the need to consider these groups as part of civil society, the focus in this chapter will largely be on NGOs and related networks given that they have been so central to transitional justice efforts in Timor-Leste.

Finally, it is important to be clear that in this chapter the nation and the state are taken as two distinct entities: the state is a set of political structures, practices and processes involved in a particular form of governance within a defined territory (and legitimated as per the above), whereas a nation - which typically encompasses a state - is comprised of people who identify with and are integrated into a particular territorial domain. For the latter, the term the 'national imaginary' is used in this

7 Judicial System Monitoring Program. 
chapter in the tradition of Benedict Anderson (1983). It is shorthand for the 'patterned convocations of the social whole' as argued by Steger and James $(2013,23)$, meaning the dominant ways the basis or parameters on which social life and collective endeavour are imagined. The national imaginary is a powerful way of understanding the connection between people, not least where independence has recently been won. Where this first section has argued that a key point of differentiation between civil society and the state are in the claims to sovereign power and the use of violence, the following section discusses how the two share the national imaginary and in turn the consequences for transitional justice.

\section{Transitional justice, the state and the national imaginary}

Arguably the three most significant transitional justice initiatives for Timor-Leste have been the Commission for Reception, Truth and Reconciliation (CAVR), the Serious Crimes Unit (SCU) and the Commission for Truth and Friendship (CTF). The CAVR was initiated in 2001 during the United Nations interregnum (from October 1999 though to May 2002) and undertook nationwide truth-telling and community reconciliation programs for less serious crimes committed during 1999. The SCU ran from 2000 through to 2005 and examined human rights abuses deemed severe, making 391 indictments over a fiveyear period ${ }^{8}$ (Kirk and da Costa Bobo 2010, 9). As a later initiative, the CTF began in 2005 as a joint Timor-Leste-Indonesia state-level effort mandated to establish the truth with regards to human rights abuses committed in 1999 (CTF 2008; Hirst 2008). Rather than being part of civil society, these three organisations are understood as para-institutions of state formed via different orders of legislated authority. ${ }^{9}$ Nevertheless, they remain important for discussion of civil society in this chapter for two reasons.

8 According to the International Center for Transitional Justice (ICTJ), of the total SCU indictments made, 84 defendants were convicted, 3 were acquitted during trial while more than 300 avoided trial as they remained in Indonesia, which would not comply with the indictments (Kirk and da Costa Bobo 2010, 9).

9 CAVR was created under the United Nations Transitional Authority for East Timor (UNTAET) via UNTAET Regulation 2001/10. It was given significant autonomy under this regulation though remained the legal creation of a transitional authority that in effect was a surrogate state. The SCU was likewise created under UNTAET Regulation 2000/11, while the CTF was created directly by both the East Timorese and Indonesian governments. 
First, the CAVR and the SCU generated significant resources that could in turn be used by civil society actors. This included the collection and publication of different kinds of information including testimonies, indictments and qualitative and statistical analysis, their efforts in organising events that linked actors and communities together, as well as giving public legitimacy to transitional justice agendas. Even though there was much criticism that the CTF was designed to absorb international critique rather than further claims for justice (Kent 2011, 449-450), its final report has also become an important resource, especially as it endorsed much of CAVR's work (Kent 2011, 450).

Second, all three institutions framed and reinforced discourses and the programmatic purpose of transitional justice as bound tightly to the new national form. The CTF was justified in terms of ensuring sustainable relations for Timor-Leste as a new nation with its former occupier Indonesia. The SCU - and a follow-up Serious Crimes Investigation Team (SCIT) - viewed prosecutions as pivotal to the sustainability of a new nation in the establishment of accountability and the rule of law, and the CAVR considered reconciliation rather than retributive forms of justice as an important step in preventing future cycles of violence. Whether moving outwards to discussions of an international tribunal, or inwards towards reconciliation at the level of local community, the national imaginary provided the cornerstone from which transitional justice agendas were formed.

This approach has appeared to be again reflected in the formation of the state-sanctioned Centro Nasional Chega! (CNC), created in late 2016 by the East Timorese Council of Ministers and inaugurated in 2017. Carrying on the tradition of CAVR and the work of the Post-CAVR Secretariat, CNC focuses on important transitional justice efforts that include memorialisation and human rights advocacy (Leach 2016, 214). Reflecting its name, CNC's remit is a national one, and thus it continues the work of threading justice and nation together in how it engages with survivors and communities. This connection has been a constant theme in academic literature over the last two decades in terms of the state (Fletcher, Weinstein and Rowen 2009; Hamber and Wilson 2002) as well as truth and reconciliation commissions (Babo-Soares 2004; McAuliffe 2008; Wilson 2003). However, here the focus is on civil society actors and the consequences of framing transitional justice within a national imaginary. 
The principal endogenous civil society actors - namely, those that have originated within and remain organisationally based within Timor-Lestewhose work has included transitional justice initiatives are NGOs, churchrelated organisations, community level activism and, in turn, associations and networks that incorporate, represent or are in part resourced by the former. For instance, East Timorese NGOs such as Yayasan Hak, Fokupers and Lao Hamutuk took leading roles in the early years of independence ${ }^{10}$ (Robie 2015, 218). Other groups joined these three as part of the TimorLeste National Alliance for an International Tribunal (ANTI), a 'coalition of organisations representing local and international NGOs, churches, students and victims' who campaigned for international mechanisms that would bring particularly Indonesian perpetrators of abuse to justice (ETAN 2004). The JSMP emerged principally to promote judicial accountability with its support of female victims of violence leading to the formation of Asistensia Legal ba Feto no Labarik (ALFela). ${ }^{11}$ Other associations and networks have included the Popular Organisation of Timorese Women (OPMT) ${ }^{12}$ that, following independence, undertook various activities including a women's history project. The 12 November Committee is comprised of victims of the 1991 Santa Cruz massacre, and the National Association of Victims and Martyrs and the Association of Ex-Political Prisoners (ASSEPOL) have represented different survivor led efforts (See Kent 2012; Rothschild 2017). In addition, Associacaon Chega! Ba Ita (ACbit) has undertaken the task of continuing to promote the work and principles of the CAVR through research and publications, as well as through initiatives such as reforming school curriculums and supporting activities for survivors. Into the early years of independence, these organisations and networks very often imbued their actions with a similar nationalism to that which fuelled their pursuit of independence, particularly the conflation of 'nation' and 'struggle'. This kind of sentiment is reflected in an interview with a RENETIL (Resistência Nacional dos Estudantes de Timor Leste) leader in 2004 where themes of struggle and liberation connect through to the national 'whole':

10 Fokupers for instance developed a database on violence against women during 1999 as well as provided support to widows post-independence, while all three organisations were advocated strongly on human rights.

11 Asistensia Legal Ba Feto no Labarik is a local NGO which provides free legal assistance to women and children.

12 Organização Popular de Mulher Timor. 
We still maintain the vision of a national liberation. In two different ways. People liberation, and country liberation. Still country liberation is relevant because we still have problem of sea border with Australia, the government ... And the second is people liberation, means liberating people from poverty, from illiteracy, from disease and so on. It's very ambitious, it's not organization vision, it's the country vision. But you take this as a kind of RENETIL vision as well, to motivate people to see the reality, not as a part but as a whole. That's why we still keep this vision as an organization vision (interview, Dili, 2004).

Here, the nation remains the motivating frame for practice. Even as a civil society organisation, the task of securing the national territory remained a priority, while the second objective was one that took 'the people' as a generalised and homogenised entity. Of relevance here is that this vision of post-independence liberation would be performed 'not as part but as a whole', a comment that is analogous in terms of scale to the quote from Andrieu $(2010,540)$ at the outset of this chapter where transitional justice is described as the transformation of 'a whole society'. In both instances the society in question is that of the nation.

Whether classified as endogenous or exogenous, CSOs in Timor-Leste have tended to work in ways that are grounded in the national imaginary. This is manifest in various ways: for instance, discursively in terms of the justification for transitional justice measures being important to the 'sustainability of the nation' or, as discussed above, to prevent cycles of violence that may put the new nation at risk. Participation of victims in programs has often been justified as an individual's or a community's role in founding the nation. It is also seen, more implicitly perhaps, in the design of programs where representatives from different locations are drawn into events, workshops and other programming efforts on the basis of ensuring national representation. Stories of abuse are told by people from an 'illustrative number' of districts in spaces supported by civil society, drawing their narratives into a national framing in a way that is repeated as compilations of testimony that are published in reports, advocacy materials and academic literature.

Concentrically related to these endogenous actors are a host of what will be categorised here as exogenous CSOs. These are organisations typified by NGOs that are globally networked such as the International Committee of the Red Cross (ICRC), the Jesuit Refugee Service, Amnesty International and the International Center for Transitional Justice (ICTJ) 
- whose authority and resource base are located beyond Timor-Leste while they are working directly on programs 'in country' and/or by the further funding of local partner organisations for projects. For instance, the International Committee of the Red Cross (ICRC) has coordinated with the Jakarta-based Asia Justice and Rights (AJAR) and the TimorLeste Red Cross to reunite families that fled Timor-Leste to Indonesia in 1999 and continues to assist with the identification of those killed during the independence struggle (ICRC 2016). Other initiatives have included the Living Memory Project driven by Australia-based activists and ASSEPOL to record the testimonies of former political prisoners, as well as teams of forensic experts from both Australia and Argentina who have worked with the 12 November Committee in searching for the remains of victims. ${ }^{13}$

In Timor-Leste, demands for justice in national terms have been reinforced, rather than negated, by these exogenous civil society actors. This might sound contradictory given that NGOs have often been seen as central to an emergent 'global civil society' (Glasius 2009, 497) that can contest or undermine national sovereignty. Yet even NGOs that are part of highly mobile networks remain bound into, and typically selforganise along the lines of, a nation-state system. Moreover, exogenous and highly globalised NGOs have often set their practice according to a 'methodological nationalism', namely a belief that the nation is the appropriate scale for political and social organisation. In other words, an aid worker may be born elsewhere but still be motivated by the task of building a sustainable 'Timor-Leste' as it is assumed that, as anywhere, the nation sets the basic parameters for political life. The following quote from an ICTJ report written by both foreigners and East Timorese typifies how human rights abuses, their effects and the need for intervention are often framed (at least discursively) in a way that takes the nation as the natural basis for justice:

Valorising victims and responding to their material needs can assist Timor-Leste's nation-building project. Although not posing a significant political threat due to their lack of organisation, victims of the past conflict represent a large, angry and disenfranchised group with a legitimate claim to reparation

13 The Jesuit Refugee Service assisted with border visits and communication between refugee groups (and resumed working with refugees during the 2006-2008 political crisis), West Timorese organisations collected information on human rights abuses in refugee camps, and other organisations such as Catholic Relief Services that have run peacebuilding programs. 
from the Timor-Leste state. By addressing victims' specific needs, Timor-Leste will combat one of the underlying causes of social disadvantage in Timor-Leste - the experience of a serious human rights violation. It will also promote an inclusive Timor-Leste society by supporting victims' ability to enjoy their rights as full citizens (Kinsella and Pereira 2010, 3).

As per the discussion above, here again the frame is the national. Where the first section of this chapter discussed key elements of civil society, the contention in this section has been that civil society actors working in the field of transitional justice have tended to take the nation as the natural platform from which discourse and practice is oriented. Civil society actors may move downwards into 'local' communities or upwards to the 'international', but these shifts are anchored in an assumption that the national is the starting point for activity. Even 'universal human rights' become embedded in national treaties. In this way, civil society often reinforces the territorial basis for states, albeit even when there is antagonism and contestation between different elements of the state. That civil society actors are geared to such a scale may not be surprising given the origin of the nationalist conflict that underpinned the creation of Timor-Leste as an independent nation-state, though as will be discussed in the following section, this has ramifications for how civil society has engaged on issues of transitional justice.

\section{The limits of national justice}

In many respects, framing transitional justice agendas in national terms might seem the most obvious way in which to secure positive outcomes for survivors. Linking the experiences of people who have suffered abuse and human rights violations with the interests of the state via a nationalist discourse could conceivably lead to broadly inclusive and empathetic forms of recognition. The careful founding of common narratives based on inclusion and difference, and the development of solidarity and compromise as a way to navigate community-wide claims for justice, could also be potential outcomes of approaching justice integrated into broader processes of nation-formation. However, this has largely not been the case in Timor-Leste, where working at the level of the nation has limited the possibilities for justice in some respects. This is explored in this final section by examining the ramifications of approaching transitional justice in close association with the state and also imagining justice on 
a macro-level. Here, and as reflected on in the following quote by McEvoy as he engages with the work James Scott, there is a continuous risk in generating interventions that are imagined at a scale that in practice may limit rather than fulfil justice:

One of the reasons Scott suggests 'state-centric' grand schemes often fail spectacularly is that they oversimplify. They may fail to take sufficient account of local customs and practical knowledge and to engage properly with community and civil society structures. Such failures, often justified in the name of efficiency, professional expertise or simply 'getting the job done', may in turn lead to incompetence or maladministration and encourage grassroots resistance to such state-led initiatives (McEvoy 2007, 424).

As suggested by McEvoy, while large-scale programs may be justified in terms of efficiency, they can fail by not being able to adapt to local intricacies. Beyond instrumental reasons of efficiency, programs may also be driven by actors that see a particular scale as appropriate, needed and justified in ideological terms, including that of nationalism. The concern here then is not that civil society is left out of consideration, but rather that civil society may take on some of the same characteristics as a state, in this instance in terms of imagining the nation as the appropriate scale by which justice is primarily located. This, it is argued, has at least two quite different ways of limiting the opportunities for transitional justice to gain traction.

In the first instance, by making a strong connection between the nation and justice, civil society actors draw debates into a framework that can be directly contested in cases of an antagonistic state. This is not to conflate the nation and the state, but rather to argue that when civil society actors frame transitional justice in national terms the topic is drawn into a domain where the state tends to be able to claim a very significant level of legitimacy. If the state takes a contrary position to civil society, the latter can become quickly outmanoeuvred and justice agendas delegitimated. In cases where a governing elite is antagonistic to particular strategies or programs, claims to know and act in the national interest can be used to contain and undermine advocacy for transitional justice measures. This is a position that can be consolidated even further in sites such as Timor-Leste where a state elite is comprised of former resistance leaders who have themselves paid heavily for their contribution to national independence. 
In Timor-Leste, political leaders have shown considerable reluctance to engage in transitional justice measures, including those proposed or initiated by civil society actors (Kingston 2006). In fact, the response from the political elite has very often been one of antagonism, particularly to agendas that have called for different forms of international accountability for human rights abuses, especially those committed by Indonesia. State responses from the East Timorese state to such agendas and advocacy have included undermining the CAVR report when it was first released, continuously delaying the debate of the CAVR recommendations in parliament, opposing the issuing of indictments by the SCU, creating organisations such as the CTF to undermine claims that an international tribunal was required, and the granting of pardons (including in contravention of the law preventing the release of indicted Indonesians who have re-entered Timor-Leste). Further to this, a governing elite has sanctioned clear hierarchies in the commemoration, recognition and distribution of resources, not only giving priority to veterans over civilian survivors but also with a clear delineation in terms of gender (Kent and Kinsella 2014). The significance of these hierarchies is that it focuses forms of recognition on former combatants for its own ends, though this has also meant that any claims for justice by or for the broader population occur without the legitimating support of the state.

The state's undermining of transitional justice agendas has occurred for domestic political reasons (for instance, to ensure veterans are seen as a priority) and also as a reflection of the desire not to antagonise its former occupier. Indonesia geographically surrounds Timor-Leste, controls the western portion of the same island as well as vital air and sea routes, and is the key source of imported goods. To be seen to be supporting civil society agendas for prosecutions or an international tribunal could potentially antagonise elements within the Indonesian state, not least the military, and create any number of potential problems for Timor-Leste.

While the placation of Indonesia has led to much criticism of former president and prime minister Xanana Gusmão (Kingston 2006), antagonism by the state can in part be understood via the distinctions made earlier in this chapter between the state and civil society. The state claims sovereign authority and, as an enabler of that, a monopoly over the legitimate use of violence. While civil society plays a role in governance - for instance, the regulation of social relations via changes in norms and behaviours frequently referred to as 'socialisation' in Timor-Leste - civil society actors do not make a claim to a legitimate use of violence. As such, 
contestation over transitional justice in Timor-Leste, and what often appears as an inappropriate level of appeasement to the Indonesians, can be understood as born out of one of the key points of differentiation between civil society and the state. As such, civil society has often approached transitional justice (especially on questions of accountability for human rights abuses) within a national imaginary that has left it vulnerable to an antagonistic state that cannot risk the same 'civic virtue'. In Timor-Leste, no matter the nationalist credentials of civil society actors, state elites have often claimed a pre-eminent relationship to the nation as a way to undermine certain transitional justice initiatives in a bid to avert risking challenges from other states to capacity to govern, including a claim to the legitimate use of violence.

While working within a national imaginary has meant that certain civil society efforts have to date been countered by the state, the second limitation discussed here relates to the effect of giving preference to the national over other more localised forms of polity. This is particularly evident when addressing the issue of the dead of war and the burial of human remains in Timor-Leste. As a result of the struggle for independence, a large number of people remain missing. Statistically it is almost impossible to know how many, though the figure has been put at the 'tens of thousands' (Robins 2010, 5). Children were forced to work with the Indonesian military and thousands were abducted and taken to live in the homes of Indonesians across the archipelago (CAVR 2005, 26). Many thousands of other people died as combatants and civilians: buried in massacre sites and temporary graves, left where they were killed, or were 'disappeared'. Since 1999, remains have been recovered through the efforts of former East Timorese commanders, forensic investigations undertaken with support from countries such as Australia and Argentina, along with support from civil society actors and by the efforts of families themselves (Kinsella and Blau 2013, 4). Many remains have yet to be located and the state's approach to the missing thus far can be described as ad hoc and at times selective, where priority is given to retrieving the remains of the political elite.

It is difficult to overestimate the importance of recovering the remains of the deceased in any circumstance in Timor-Leste, even more so when the person has died or been killed through violent events (Bovensiepen 2014, 116). Of fundamental importance is ensuring that the spirits of the deceased are shown proper respect. Following funerary rituals is key 
in fulfilling this need. An unnatural or violent death, or one where the death incurs a sense of debt to those still alive, can mean a spirit is left in a restless state and can be a source of potential risk to the living. Poor health, misfortune and accidents are often understood as being caused by angry ancestors. This is not a secondary or residual element in Timorese culture, but is frequently expressed as foundational to understanding why and how things happen to people. Often scarce resources are deployed to ensure recognition. The need to recover the remains of the dead, or to undertake surrogate forms of recognition, is considered of paramount importance (Winch 2017).

The burying of former veterans in the 'national heroes' cemetery in TimorLeste, or in one of the various ossuaries that have been built in regional centres around the country, ensures that these deaths are irrevocably tied to the formation of the nation (Viegas and Feijó 2017). And yet these bodies and their spirits, along with the thousands of non-combatants killed in the war, are very often connected into a different community comprised of the living and the ancestral domain, via association with an uma lulik (sacred house). This is a kind of 'customary polity' that exists across a different kind of space and time to that of the nation (Grenfell 2015) where there is a specific and exclusive affiliation to one sacred house.

On issues of transitional justice, civil society actors may reach into the local levels and gather the most intimate stories of abuse, but these stories are elevated and recalibrated via workshops, research, training, advocacy and campaigns as if part of a national 'whole'. Even as civil society has shifted its focus from an international tribunal to reconciliation, reparations and the rights of survivors (and has recognised the need to include more space for their voices) (Kent 2012, 194-195), the national imaginary still figures as the natural basis from which organising occurs: from how initial engagement with communities is framed and legitimated, to how programs are designed in terms of lifting discreet communities into common dialogue and, in turn, to how final presentation of facts are framed in national terms. This may have some benefits, but such an approach should also be met with some caution.

Drawing testimony from victims in order to advocate on their behalf for reparations, or to create a record of their struggle as a public good, presents risks when people are drawn into a domain where there are not the resources or political will to, in turn, ensure adequate recognition and 
action. ${ }^{14}$ Testimony can lead to a sense of emptiness rather than fulfilment and, as Simon Robin's work attests, it can lead communities who do not receive hoped-for outcomes to disengage from the efforts of civil society:

Like from the Red Cross, they came here last year and informed us that, for those who had lost their family and did not find their bones yet, you come together here so we can find ways or solutions to resolve this problem, and afterwards we never heard anything again from them and it seems they lost it [the bones] on the way. As we said before the Red Cross also came here, collected all our names, they brought the entire list but where are they now; they have probably thrown them away or thrown them in the garbage. That is why we as the family of the victims, we find it hard to meet or talk to you people, as if you came now. Because so many interviews on the same topics have been made with us as the victims' family but they never yield any result (Focus group participant, Bobonaro) (Robins 2010, 32).

Whether this is a common experience or otherwise is not the point. Rather, what is important are the dynamics that produce antagonism or indifference to efforts that are framed as assisting the community. ${ }^{15}$ Either way, such a sentiment is indicative of the kind of dilemma where the experience of personal trauma and abuse is elevated into a national discourse without the necessary resources or political motivation at that level to respond adequately. Asking for people's participation raises expectations and when these remain unfulfilled then people may choose to withdraw. This is even more difficult when there is a failure to recognise the implications for customary practice. Giving testimony means to 'konta uluk' - to talk about the past. Yet, to speak about the dead and then not respond with action is to risk the wrath of one's ancestors (Robins 2010); the ancestors are listening and their own heightened expectation of recognition and peace may lead to reprisal if left unmet.

14 This is not to say that there are not advantages for people in the way that testimony has been collected, as it may assist with the return of remains for instance, or with end results that assist with everyday needs including spiritual. There may also be therapeutic and social advantages in drawing victims together to share and be afforded some level of public recognition, even more so in instances where the state has not provided adequate levels of recognition.

15 See also Lia Kent's 'Sounds of Silence' (2016) for her analysis of silence, in this instance for reasons of pragmatism as well as civility. 


\section{Conclusion}

The establishment of the Centro Nasional Chega! over 2016 and 2017 may give a new momentum to the transitional justice agenda in TimorLeste. And it is not insignificant that this body was formed by the Council of Ministers, thus suggesting that both difference and space may exist at the upper levels of state for certain transitional justice agendas to be recognised. Given the above arguments, the CNC could also be an opportunity to explore different ways forward in terms of how discourses, activities and strategic objectives are formulated and enacted. It may mean that working locally, for instance, is given emphasis and in a way where what the nation means to people evolves as one part and one layer to how justice is approached. If this is to occur, however, it is important that consideration is given to how different actors - including civil society - interact with local communities and the way priorities and needs are expressed to emanate outwardly from that level. Again, this may mean that survivors will choose to speak in terms of the nation as part of that discourse. However, it may also give survivors the space necessary to forge a localised form of recognition that answers to customary sociality while also finding avenues for recognition and reconciliation at the national level in a way that is negotiated with and supported (rather than contested) by the state. This might enable a new and necessary space for justice to be imagined.

\section{Bibliography}

Anderson, Benedict. 1983. Imagined Communities: Reflections on the Origin and Spread of Nationalism. London: Verso Books.

Andrieu, Kora. 2010. 'Civilising Peacebuilding: Transitional Justice, Civil Society and the Liberal Paradigm'. Security Dialogue 41 (5): 537-558. doi.org/10.1177/ 0967010610382109.

Asosiasaun HAK. 2014. 'Relatoriu Monitorizasaun Direitus Umanus Periodu Fevreiru - Abril 2014'. Civil Society Monitoring Report, Centre for Global Research Timor-Leste Library, Melbourne.

Babo-Soares, Dionísio. 2004. 'Nahe Biti: The Philosophy and Process of Grassroots Reconciliation (and Justice) in East Timor'. The Asia Pacific Journal of Anthropology 5 (1): 15-33. doi.org/10.1080/1444221042000201715. 
Bell, Christine and Catherine O’Rourke. 2007. 'The People's Peace? Peace Agreements, Civil Society, and Participatory Democracy'. InternationalPolitical Science Review 28 (3): 293-324. doi.org/10.1177/0192512107077094.

Belun. 2017. 'From Kindergarten to High School': Perceptions of Timor-Leste's Military and Police Ten Years after the 2006 Crisis. Dili: Belun.

Bovensiepen, Judith. 2014. 'Paying for the Dead: On the Politics of Death in Independent Timor-Leste'. The Asia Pacific Journal of Anthropology 15 (2): 103-122. doi.org/10.1080/14442213.2014.892528.

Brahm, Eric. 2007. 'Transitional Justice, Civil Society, and the Development of the Rule of Law in Post-Conflict Societies'. International Journal for NotFor-Profit Law 9 (4): 62-69.

CAVR (Commission for Reception, Truth and Reconciliation). 2005. Chega! The Final Report of the Timor-Leste Commission for Reception, Truth and Reconciliation (CAVR). Dili: Post-CAVR Technical Secretariat.

CTF (Commission for Truth and Friendship). 2008. Per Memoriam Ad Spem: Final Report of The Commission for Truth \& Friendship (CTF) IndonesiaTimor-Leste. Denpasar: Commission for Truth \& Friendship IndonesiaTimor-Leste.

Cubitt, Christine. 2013. 'Constructing Civil Society: An Intervention for Building Peace?’ Peacebuilding 1 (1): 91-108. doi.org/10.1080/21647259. 2013.756274.

Escollano Brandão, Constantino da Conçeição Costa Ximenes. 2015. Istoria Ezistensia CPD-RDTL no Implikasaun sira ba Futuru Estadu Demokratiku. Policy Brief No. 10, Dili: Early Warning Early Response (Belun).

ETAN (The East Timor National Alliance for an International Tribunal). 2004. 'Statement to the Technical Assessment Mission from United Nations Headquarters, New York'. ETAN, 15 January 2004. etan.org/news/2004/ 01alliance.htm.

Fletcher, Laurel E., Harvey M. Weinstein and Jamie Rowen. 2009. 'Context, Timing and the Dynamics of Transitional Justice: A Historical Perspective'. Human Rights Quarterly 31: 163-220. doi.org/10.1353/hrq.0.0058.

Foley, Michael W. and Bob Edwards. 1996. 'The Paradox of Civil Society'. Journal of Democracy 7 (3): 38-52. doi.org/10.1353/jod.1996.0048.

Gerth, Hans H. and Charles W. Mills. 1946. From Max Weber: Essays in Sociology. New York: Oxford University Press. 
Glasius, Marlies. 2009. 'What is Global Justice and Who Decides? Civil Society and Victim Responses to the International Criminal Court's First Investigations'. Human Rights Quarterly 31 (2): 496-520. doi.org/10.1353/ hrq.0.0075.

Gray, Rob, Jan Bebbington and David Collison. 2006. 'NGOs, Civil Society and Accountability: Making the People Accountable to Capital'. Accounting, Auditing \& Accountability Journal 19 (3): 319-348. doi.org/10.1108/ 09513570610670325.

Grenfell, Damian. 2015. 'Of Time and History: The Dead of War, Memory and the National Imaginary in Timor-Leste'. Communication, Politics \& Culture 48 (3): 16-28.

Grenfell, Laura. 2009. 'Promoting the Rule of Law in Timor-Leste'. Conflict, Security \& Development 9 (2): 213-238. doi.org/10.1080/14678800902925143.

Hamber, Brandon and Richard A. Wilson. 2002. 'Symbolic Closure through Memory. Reparation and Revenge in Post-Conflict Societies'. Journal of Human Rights 1 (1): 35-53. doi.org/10.1080/14754830110111553.

Hirst, Megan. 2008. Too Much Friendship, Too Little Truth: Monitoring Report on the Commission of Truth and Friendship in Indonesia and Timor-Leste. New York: International Center for Transitional Justice.

Holloway, Richard. 2004. 'What is Civil Society in Timor-Leste?' Non-peer reviewed article, Centre for Global Research Timor-Leste Library, Dili.

ICRC (International Committee of the Red Cross). 2016. 'Indonesia and Timor-Leste: Facts \& Figures, January-September 2016’. ICRC, 20 October. www.icrc.org/en/document/indonesia-timor-leste-facts-figures-januaryseptember-2016.

Kent, Lia. 2011. 'Local Memory Practices in East Timor: Disrupting Transitional Justice Narratives'. The International Journal of Transitional Justice 5 (3): 434-455. doi.org/10.1093/ijtj/ijr016.

Kent, Lia. 2012. The Dynamics of Transitional Justice: International Models and Local Realities in East Timor. Abingdon: Routledge.

Kent, Lia. 2016. 'Sounds of Silence: Everyday Strategies of Social Repair in TimorLeste'. Australian Feminist Law Journal 42 (1): 31-50. doi.org/10.1080/ 13200968.2016.1175403.

Kent, Lia and Naomi Kinsella. 2014. 'A Luta Kontinua (The Struggle Continues)'. International Feminist Journal of Politics 17 (3): 473-494. doi.org/10.1080/ 14616742.2014.913383. 
Kingston, Jeffrey. 2006. 'Balancing Justice and Reconciliation in East Timor'. CriticalAsianStudies38(3):271-302.doi.org/10.1080/14672710600871430.

Kinsella, Naomi and Soren Blau. 2013. 'Searching for Conflict Related Missing Persons in Timor-Leste: Technical, Political and Cultural Considerations'. Stability 2 (1): 1-14. doi.org/10.5334/sta.au.

Kinsella, Naomi and Manuela L. Pereira. 2010. Unfulfilled Expectations: Victims' Perceptions of Justice and Reparations in Timor-Leste. Brussels: International Center for Transitional Justice.

Kirk, James and Carlito da Costa Bobo. 2010. Impunity in Timor-Leste: Can the Serious Crimes Investigation Team Make a difference? New York: International Center for Transitional Justice.

Kovras, Iosif. 2012. 'Explaining Prolonged Silences in Transitional Justice: The Disappeared in Cyprus and Spain'. Comparative Political Studies 46 (6): 730-756. doi.org/10.1177/0010414012463879.

Labigne, Anaël and Anne Nassauer. 2012. 'Violence in Civil Society: Insights from the CSI Databases'. In Conflict and Violence: Insights from the CIVICUS Civil Society Index Project, edited by Wolfgang Dorner and Regina A. List, 127-143. London: Bloomsbury Academic.

Lambourne, Wendy. 2009. 'Transitional Justice and Peacebuilding after Mass Violence'. The International Journal of Transitional Justice 3 (1): 28-48. doi.org/10.1093/ijtj/ijn037.

Leach, Michael. 2016. The Politics of Timor-Leste: Democratic Consolidation after Intervention. Ithaca: Cornell University Press. doi.org/10.22459/NE.09. 2015.04 .

McAuliffe, Pádraig. 2008. 'East Timor's Community Reconciliation Process as a Model for Legal Pluralism in Criminal Justice'. Law, Social Justice and Global Development 12 (1): 1-21 (online journal).

McEvoy, Kieran. 2007. 'Beyond Legalism: Towards a Thicker Understanding of Transitional Justice'. Journal of Law and Society 34 (4): 411-440. doi.org/ 10.1111/j.1467-6478.2007.00399.x.

Minow, Martha. 2002. 'Breaking the Cycles of Hatred'. In Breaking the Cycles of Hatred: Memory, Law and Repair, edited by Martha Minow and Nancy L. Rosenblum, 14-76. New Jersey: Princeton University Press.

RDTL (República Democrática de Timor Leste). 2015. 'Regrettably, Mauk Moruk Killed in the Joint Operation'. Media Release, 8 August 2015. timor-leste.gov. $\mathrm{tl} /$ ?p=13009\&lang=en. 
Robie, David. 2015. 'La'o Hamutuk and Timor-Leste's Development Challenges: A Case Study in Human Rights and Collaborative Journalism'. Media Asia 42 (3-4): 209-224. doi.org/10.1080/01296612.2016.1142247.

Robins, Simon. 2010. An Assessment of the Needs of Families of the Missing in Timor-Leste. York: Post-War Reconstruction and Development Unit (PRDU), University of York.

Rothschild, Amy. 2017. 'Victims Versus Veterans: Agency, Resistance and Legacies of Timor-Leste's Truth Commission'. International Journal of Transitional Justice 11 (3): 443-462. doi.org/10.1093/ijtj/ijx018.

Shils, Edward. 1995. 'Nation, Nationality, Nationalism and Civil Society'. Nations and Nationalism 1 (1): 93-118. doi.org/10.1111/j.1354-5078.1995.00093.x.

Steger, Manfred B. and Paul James. 2013. 'Levels of Subjective Globalization: Ideologies, Imaginaries, Ontologies'. Perspectives on Global Development and Technology 12 (1-2): 17-40. doi.org/10.1163/15691497-12341240.

Viegas, Susana de Matos and Rui Feijó. 2017. 'Territorialities of the Fallen Heroes'. In Transformations in Independent Timor-Leste: Dynamics of Social and Cultural Cohabitations, edited by Susana de Matos Viegas and Rui Graça Feijó. London and New York: Routledge. doi.org/10.4324/9781315535012.

Walzer, Michael. 1992. 'The Civil Society Argument'. In Dimensions of Radical Democracy: Pluralism, Citizenship, Community, edited by Chantal Mouffe, 89-107. London: Verso.

Wilson, Richard A. 2003. 'Anthropological Studies of National Reconciliation Processes'. Anthropological Theory 3 (3): 367-387. doi.org/10.1177/14634 996030033007.

Winch, Bronwyn. 2017. "La iha Fiar, la iha Seguransa”: The Spiritual Landscape and feeling secure in Timor-Leste'. Third World Thematics: A TWQ Journal 2 (2-3): 197-210. doi.org/10.1080/23802014.2017.1320200. 
This text is taken from Civil Society and Transitional Justice in Asia and the Pacific, edited by Lia Kent, Joanne Wallis and Claire Cronin, published 2019 by ANU Press, The Australian National University,

Canberra, Australia.

doi.org/10.22459/CSTJAP.2019.02 